\title{
ELECTION RIGGING AND THE USE OF TECHNOLOGY: \\ The Smart Card Reader as the Joker in Nigeria's 2015 Presidential Election
}

\author{
Osita Agbu \\ Osita Agbu is a Professor and Head of the Division of International Politics \\ in the Research and Studies Department, Nigerian Institute of \\ International Affairs \\ email: ossele2004@yahoo.com
}

\begin{abstract}
Elections provide the platform for political succession in Nigeria, as elsewhere. They used to provide an opportunity for fraudulent individuals and groups to perpetrate acts of rigging against both other contestants and the electorate. Through no fault of their own stakeholders and the electorate are sidelined through unbridled rigging, thus losing the election or having their votes stolen or cancelled. This was the situation until the arrival of the permanent voter's cards and the smart card reader. This technological input in Nigerian electoral space made it extremely difficult for results to be manipulated, either by anonymous individuals or through arbitrarily and fraudulently manipulating figures. The transparent application of this electronic device and its embodied security features make it extremely difficult to clone or compromise. This paper, therefore, intends to explore the circumstances that warranted the use of the smart card reader, the polemics surrounding its use, its performance during the 2015 presidential elections, as well as its potential for future elections.
\end{abstract}

\section{INTRODUCTION}

What we aim to achieve is that with the 2015 general election, Nigeria will take its rightful place in the global order of nations where electoral democracy has come of age. That is our goal, and we have an unflinching commitment to it. 
It is this writer's belief that the Chairman of the Independent Electoral Commission (INEC), Professor Attahiru Jega, and his team were able to conduct a credible general election in 2015. Going by his previous experience, Jega and his team displayed a high level of integrity and innovative spirit in the organisation and management of the election. In the aftermath of the elections it is time to reflect on and identify what did and did not work, especially against the backdrop of national and global fear that violence would overtake the election and that the Nigerian state might implode. This doomsday feeling and predictions by many about the election was not borne out by the apparent success of the 2015 general elections in Nigeria. This paper discusses whether this success could be attributed to a single factor or a combination of factors, and the extent to which technology, that is the use of the permanent voter's card (PVC) and smart card reader (SCR), made a significant contribution to the election.

From the time of the First Republic, Nigeria's electoral history has been characterised by grave incidences of electoral rigging. Eguavoen (2009, p.27) correctly observes of Nigerian politics that the country has never had crisis-free and fair elections. Elections in Nigeria have never been devoid of malpractice and violence. After attaining political independence in 1960, Nigeria had a parliamentary system of government. During the general elections four years later Nigeria ran into serious problems. Accusations and counter-accusations of fraud and malpractice were widespread, with many lives lost and property destroyed. Political crises eventually led to the first military coup d'état in January 1966. Therefore, the successes achieved in the 2011 and 2015 elections should not simply be glossed over. They were major achievements that need to be dissected and documented in anticipation of future elections. Despite some disagreement with this perspective our hope is that these misgivings may be laid to rest.

Winning elections in Nigeria is a serious business because it is a sure way of accessing state resources. As an aspiring democratic state, periodic free and fair elections are one of the pillars for sustaining democracy. Defined as a procedure that allows members of a state, organisation or community to choose representatives who will hold positions of authority within it, and which promotes public accountability, elections are critical in ensuring participatory governance. As we know, the concept of democracy is not necessarily synonymous with elections; however, a free and fair (credible) election is generally accepted to be at the heart of democracy. A free and fair election is a desideratum for the existence of democracy. A democratic government ideally denotes government composed through the freely given consent of the people as expressed in an election. Once the element of free consent is absent in an electoral process, then the outcome is no a longer democracy, but dictatorship (Aborisade 2006, p.115). Any election fraught with fraud and violence is therefore a usurpation of the sovereignty of 
the people, the equivalent of an electoral coup. Further, elections are one of the most important means of establishing legitimate government and exercising popular control over leaders. It is also a means of policy selection as set out in party manifestos during elections. An election is a process, and it is free if all stages of the process are devoid of inhibitions and contradictions. It is also fair if the process shows no favour to person, party or side. Fairness means acting in an honest and honourable manner that is in accordance with what is desirable according to rules (Okoh 2005, p.24).

For Adebisi (2005, p.18), as quoted by Sarah Birch, a global authority on the subject of election malpractices, electoral malpractices could occur in three principal ways, namely:

- Manipulating the design of institutions governing elections to the advantage of one or more electoral contestants in violation of the principles of inclusivity, impartiality, openness or transparency, such as through gerrymandering, malapportionment, over-restrictive franchise or candidacy regulations.

- Campaign regulations that lead to inequalities among contestants.

- Lack of observer access to electoral processes.

However, what Birch did not envisage is that electoral malpractices could have a primordialist slant, largely unbridled and unfettered, and perpetuated with violence and impunity. This was particularly true of Nigeria before the general elections in 2011 and 2015. These malpractices were often effected with the active connivance of government authorities, compromised security and INEC officials, and corrupt politicians. This was a manifestation of the character of the Nigerian state.

\section{THE NIGERIAN STATE AND UNBRIDLED ELECTION RIGGING}

The penchant for violence and election rigging in Nigeria's electoral democracy needs to be understood in terms of the character of the Nigerian state and its aversion to transparency and accountability in the electoral process. Indeed, there is a running battle between primordialist forces and progressives over the ownership of the state. The character of the Nigerian state and society is fundamentally anarchical, mainly as a result of the multiplicity of ethnic groups and the political economy of the entity. This is largely a mono-product economy superintended by a distorted federal structure (Agbu 2016). Its political structure and governance have been distorted since political independence in 1960: first, by colonialists; second, by the ethnicised political class; and thirdly, by military 
politicians. The character of the Nigerian state therefore derives from the various experiences of the past as experienced under colonial rule, the various attempted, aborted and successful coups d'état (eleven as at the last count in 1997), ethnic politics, the civil war (1967-1970) as well as deep-rooted distrust among some of the ethnic nationalities, and settler/indigene crises across the country (Moru 2004). These experiences have continued to shape the structure and dynamics of the Nigerian state. Unfortunately this structure is generally believed to facilitate a rentier and nepotic system which undermines creativity and elevates the mediocrity preferred by primordialist forces. This situation is extrapolated to the electoral process, which unfortunately is a zero-sum game with the prize going to the person or group that can out-rig all the others. To this extent, access to power and its use for primitive accumulation and influence have become an internecine affair. In this struggle for primitive accumulation, the state is not neutral but is an active participant; indeed, it became an instrument of the class that had captured the state. The dominant political class used state power for survival and reproduction. This accounts for the persistent incidence of electoral fraud and violence. The state, its structure, institutions and apparati were instruments of domination, tenure extension and preservation (Okolie 2005, p.435). This explains why the law enforcement agencies, INEC and some of its officials were used to pervert the rule of law and disenfranchise the electorate in an unbridled manner. For several decades Nigerian politics became a subject that many felt should be discussed rather than practised because of the violence, fraud and risk involved (Opeibi 2009).

The elective principle was first introduced into Nigeria's electoral system in 1923 because of the corruption and money politics that characterised the electoral college system (Babalola 2003, p.8). This reduced corruption and money politics but failed to eliminate them. Although the 1979 constitution was a watershed experience in Nigeria's constitutional development, subsequent party politics were not much different from post-independent Nigeria. Political parties were formed largely along ethnic lines, while the political class politicised the ethnic divides. The Nigerian state was to witness a further crisis relating to revenue allocation, state creation, civil war, power-sharing, sectarian crises, and coups d'état that almost led to its disintegration. Since then, Nigeria has been bedevilled by claims of marginalisation, separatist agitations, and resource control, attesting to the distorted nature of its political structure, and calls for its re-structuring.

It is widely accepted that the political centre of the neo-liberal state in Nigeria had been captured by state, corporate interests and ethnic bigots. Thus political parties are bogged down in primitive accumulation or corruption, not the idea of serving the Nigerian people. Inadvertently, political parties promote the neo-liberal culture of celebrating the cult of the individual, selfishness, greed 
and the validation of electoral riggers as winners. In such a framework, political gangsterism or 'garrison politics' become the order of the day. The task today is how to understand and eschew the confusion arising from this.

However, in the current age of globalisation, the dictates of global governance and democratisation require that countries comply with certain standards, and these standards are further propelled by technology, especially communication technology. The framework of our discourse is therefore anchored in understanding the character of the Nigerian state, and the imperative of embracing technology as applied to the electoral process. In this case, these are the progressive forces as encapsulated in the general theory of technology (Markus \& Robey 1988). For many Nigerians the question is how to make their votes count in this political environment. For many progressives the choice was simple - to embrace the PVC and SCR.

Various frameworks have been used to explain the application of technology in society. Many of these theories could be categorised into descriptive and critical theories, while others are simply new propositions that remain unclaimed. Descriptive theories attempt to interrogate the link between technology and society through the definition and substance of technology, its emergence and changes in relation to the human/social sphere. Critical theories on the other hand use descriptive theories to search for ways to change the relationship between technology and society. Therefore, it becomes imperative for critical theories to be on the front burner, anticipating change. Some of the more common theories include the social construction of technology (Mackenzie \& Wajcman 1985), systems theory (De Santis \& Poole 1990), and the media richness theory (Daft \& Lengel 1986). In more recent times, the following theories have also been used to explain the role of technology in the electoral process: rational theory (Enwere \& Laden-Baki 2015), cultural relativism (Idike 2014), cybernetics model of communications theory (Nwangwu 2015), and the linguistic and discursive analytic perspective (Opeibi 2009). Broadly, we here apply Markus \& Robey's general technology theory as an analytic tool. It presents the causes, structures of agency (technological, organisational, imperative, and emergent); structure (variances and processes) and the level of analysis (micro, macro). In this case, it is the imperative of devising or embracing technology that can check the endemic problem of election rigging that necessitated the use of electronic accreditation for the presidential election. While the Nigerian state, INEC and the electorate are key stakeholders and provide different levels of analysis, it is ultimately the goal of achieving a credible election and making votes count that provides the motivating force in the relationship between artifact and society.

Furthermore, the Internet and the expansion of communication networks which goes with it, appear to be the most important technology affecting the world 
at present. Despite the importance of the Internet today, there is still some cultural lag whereby culture takes time to adjust to the material conditions embodied in technological change (Gyford 2011). We note this against the background of those theories that suggest that technology changes society, rather than vice versa. The general technology theory attempts to addresses the relationship between technology and society and raises questions of agency, determinism and autonomy. In the Nigerian case, it is the need to devise a reliable way to halt election rigging that led to the use of the PVC and SCR. In other words, societal imperative led to the use of the technology and not vice versa.

Permutations of ICT in electoral processes such as e-voting, its adoption and diffusion, could lead to significant improvement in democratic practices in various democracies around the globe. This phenomenon profoundly influenced Nigerian policy makers to explore the viability of adopting e-voting in their public elections (Ahmada et al. 2015, p. 95). The Chairman of INEC, Attahiru Jega, asserted that '... the whole world is moving in the direction of increasing the use of technology in order to have credible elections' (Jega \& Hillier 2012). As observed by Levan and Ukata (2012), there are various factors that are bound to challenge the performance of the traditional paper ballot system of elections in Nigeria. These include the difficult topographical terrain of some communities in Nigeria, the movement of both the electorate and electoral officials as well as election materials to polling units and collation centers, and the tallying and collation of results. Moreover, communicating election results using traditional means of transportation expose the results to numerous risks such as attack by political thugs, aggrieved party members, or manipulation by corrupt officials. These constraining factors question the continued use of the traditional paper ballot system and therefore open up a window for the e-voting option (Jega \& Hillier 2012).

INEC was faced with the problem of how to deal with electoral rigging and polling unit politics. After much critical thinking, consultation and research they endorsed aggressive voter education in order to check polling unit politics, and deployed SCR to reduce the growing incidence of election rigging and overinflated votes. However, before the SCR was introduced, INEC had painstakingly worked out the modalities of this sophisticated device. This included switching to the manual method of accreditation and resetting the SCR in case of any anomaly associated with the device; and they also analysed its merits and demerits (Enwere \& Ladan-Baki 2015).

Since political independence, Nigeria's democratisation has witnessed massive electoral fraud characterised by violence. This has compromised the ethics of democracy despite several electoral reforms that had little impact on the electoral process. Electoral fraud, which can also be referred to as election rigging, is described as electoral malpractice. These are palpable illegalities committed 
with corrupt, fraudulent or sinister intention to influence, intimidate and foist other acts of coercion on voters, including the falsification of results and fraudulent announcement of a losing candidate as a winner.

Nigeria has conducted five elections since 1999, comprising the 1999, 2003, 2007, 2011 and 2015 general elections respectively. Except for the elections in 2011 and 2015 they were all roundly condemned for not meeting the required global standards and were therefore not considered credible.

For example, rigging in the 2003 general election was simply rampant. Some results were said to have been written in the private homes of individuals, and in some cases, announced even when the elections had not been conducted (Eguavoen 2009, p.28). In other places, fictitious thumb-printed ballot papers were stuffed into ballot boxes and used to compute figures for pre-determined winners. Security agents were used by government to intimidate and harass the electorate in different parts of the country. Money was used to influence the electorate to vote for unpopular candidates. In fact, the European Union Election Observer Mission (EU-EOM) Team led by Max van den Berg mentioned 12 States where fraud and irregularities were rampant and concluded that the 'minimum standard for democratic elections were not met' (NDI 2003, p.30).

Furthermore, the general elections of April 2007 were characterised by several challenges and shortcomings. These were as a result of poor preparation and widespread manipulations of the electoral process by the government using law enforcement agencies, especially the police and the Economic and Financial Crimes Commission (EFCC). The irregularities in this election included the late arrival of materials and officials, stealing of ballot papers, vote buying, harassment, chanting, shooting and taunting of voters, lack of secret voting, police interference, ballot snatching and stuffing, intimidation and political violence, denial of access to polling stations, partiality of electoral officials and the police, improper voting procedures, late commencement of elections, and underage voting (TMG 2007, p. 132). After evaluating the reports of observers deployed throughout the country, the Domestic Election Observation Group noted that numerous lapses, massive irregularities and electoral malpractices had been documented, and came to the conclusion that the whole election was a charade and did not meet the minimum standards required for democratic elections (TMG 200, p.136).

Whilst the 2015 general elections were declared largely free, fair and credible by most local and international observers, there are some who think otherwise, pointing out incidences of what they consider to be electoral fraud. The aim of this paper is to provide convincing evidence endorsing the claim that the PVC and SCR were indeed, the jokers in the pack, used to ensure freer, fairer and more credible 2015 general elections in Nigeria, in comparison to past electoral practice. 


\section{THE PRE-ELECTION ENVIRONMENT AND ELECTION RIGGING}

Since the institution of an election is a process, it is necessary to examine the environment under which the 2015 presidential election was held. This was an environment that was already charged, and in which the electoral management body, INEC, was constantly under scrutiny. Many - and not just politicians believed that its leadership was already compromised in favour of the ruling party, the Peoples Democratic Party (PDP). This belief was not far-fetched, since except for a few instances, experience showed this to be true of the other management bodies and their staff. To many, the result of the election had already been decided. Nevertheless, the emergence of the two key political actors, President Goodluck Jonathan and General Muhammadu Buhari (Rtd), both with political pedigree, and with Buhari having immense followership in the northern part of the country, indicated that this election was going to be different in the sense that it would be keenly contested.

In the run-up to the election, there was a reckless use of the police and military in Ekiti and Osun States; also the use of firearms by PDP thugs in Edo State in collusion with the police to vandalise the Edo State House of Assembly residential quarters. There were also constant machinations to humiliate the Rivers State Governor Rotimi Amaechi employed by his political opponents (OdigieOyegun 2014). Furthermore, in Edo State the police continued to disobey the orders of both the High Court and the Court of Appeal. In Ekiti State, the police looked the other way when judges were beaten up, and democratically-elected principal officers of the State House of Assembly were sacked by only six of 26 elected members.

As the general elections approached, concerns mounted that the elections would generate violence, chaos and anarchy as many politicians jostled for positions. Nigerians were indeed apprehensive that there might be conflict and violence with serious implications for the stability of the country. Indeed, the suspicion was that fear of political violence and personal harm deterred many voters, especially in the south west and south east of the country, from coming out to cast their votes. This is against the backdrop of the unnecessary deaths of 943 persons, with 838 injured in the aftermath of the 2011 presidential election (Idowu-Fearon 2014, p.17). The primaries conducted by the various political parties did not give much hope that lessons had been learned from the processes of the 2011 general elections. Internal democracy within the parties remained a mirage as parties still engaged in the imposition of candidates and disregarded agreed modalities for contesting political office, while politicians schemed how to remain in power at all cost. 
The consequences of the failure of the 2015 general elections were too grim to contemplate. As early as four weeks before the elections, Nigeria was at the forefront of global attention, with personalities like Kofi Annan, former SecretaryGeneral of the United Nations, and Emeka Anyaoku, former Secretary-General of the Commonwealth, working to create a less acrimonious atmosphere for the presidential election. This resulted in several prominent Nigerians brokering the peace deal between incumbent President Goodluck Jonathan and the tenacious General Muhammadu Buhari, the candidate of the All Progressives Congress (APC). In addition, prominent ex-presidents from Africa visited Nigeria and added their voices to the need for a peaceful election. These were Thabo Mbeki from South Africa, John Kuffor from Ghana, as well as Abdusalami Abubakar of Nigeria. Even the American Secretary of State, John Kerry, came around soliciting peaceful elections, with subtle threats to recalcitrant politicians who did not keep the peace (Osundare 2015, p.28). British Prime Minister David Cameron registered his own concern and encouragement for the process; the European Union was not silent, while Ban Ki-Moon, the UN Secretary General, cabled the anxiety of the international community. Only a few hours before the election, President Barak Obama of the United States broadcast his own message by video to the Nigerian people and their rulers (Osundare 2015). Indeed, it was clear to all that the success of this election was important to the global community, and for democracy in Africa.

Prior to the elections, INEC had set in motion various reform measures to ensure credible and successful elections. Some of the measures were initially introduced for the 2011 elections with appreciable results and implications for the 2015 elections, and include:

- A new biometric register of voters

- A re-modified open ballot system (REMOBS)

- Improved standards in the production of sensitive electoral materials (serial numbering and colour-coding of ballot papers and results sheets as well as security coding of ballot boxes)

- Revised framework for results collation and returns

- More open and transparent procedures, modalities and processes on election day (posting results at polling units and collation centres)

- Improved voter education and citizen engagement

- Creation of an inter-agency consultative committee on election security (ICCES) to ensure coordinated engagement of all security agencies during election periods 
Since the 2011 elections, INEC had spent adequate time reviewing and preparing a better framework for the conduct of subsequent elections that involved INEC staff, security agencies, development partners, the media and political parties. Lessons from the 2011 elections included:

- Good elections require adequate and timely planning.

- Good elections are about effective partnerships and cooperation.

- Good elections are about openness.

- Finally, elections cannot be perfect.

Based on the experiences of the 2011 elections, INEC began to plan early for the 2015 elections with a view to consolidating the gains from the 2011 elections. Three focal points of structure, policy and plan were articulated; taking a hard look at INEC as an institution in respect of structure and human resources, as well as developing new policies on election management, and strategic planning and election planning. In summary, the commission prepared for the 2015 elections as follows:

- Formulated a strategic plan (2012-2016), and a detailed strategic programme of action.

- Completed a detailed election project plan leading up to the 2015 elections.

- Conducted reorganisation and restructuring of the commission.

- Finalised the de-duplication of the biometric register of voters that included continuous voter registration nationwide.

- Drafted a gender policy intended to make the commission's work more gender sensitive, in line with global best practice.

- Recommended improvements to the legal framework based on experiences from the 2011 elections, for constitutional action and on the Electoral Act.

- Re-organised the Electoral Institute, with the appointment of a new Director-General and reconstitution of its board.

- Established a graphic design centre with support from the International Foundation for Electoral Systems (IFES), which for the first time gave the commission the capacity to produce election materials internally.

- Embarked on a programme to review electoral constituencies and remap/reorganise polling units 
These were some of the reforms taken by INEC in the run-up to the 2015 elections. However, the most novel strategic measure taken was the introduction and use of the permanent voter's cards and smart card reader. This was the 'joker' that made it extremely difficult to rig the elections, despite the efforts made by desperate politicians to scuttle the use of this device. It is evident from the exertions of INEC in preparing for the election that this was the main, but not only reason for the success of the 2015 elections, regardless of opinions to the contrary. Anticipated challenges to the 2015 elections included insecurity, especially in the north east of the country, and its implications for conduct of elections; funding; the attitude of the political class; and citizen apathy. Indeed, INEC's efforts at creating more polling units met with stiff opposition from some of the stakeholders who believed that this was the fore-runner to rigging the election. However, it appears that these challenges were significantly surmounted as the elections proceeded.

\section{PERMANENT VOTER'S CARDS AND SMART CARD READERS: THE TRIUMPH OF TECHNOLOGY}

We begin this section by understanding what the permanent voter's cards (PVC) and smart card readers (SCR) are, and what they were expected to do during the elections.

\section{Permanent Voter's Cards (PVCs)}

The Independent National Electoral Commission produced PVCs for 68833476 persons in the biometric register of voters ahead of the March $28^{\text {th }}$ and April $11^{\text {th }}$, 2015 general elections. The PVC replaced the temporary voter card (TVC) issued on the heels of voter registration in 2011. According to INEC, quality, security, durability and cost effectiveness were underlying factors in the production of the permanent voter's cards by INEC. These cards have many components and specialised features (e.g. base substrate, security printing, personalisation, lamination and chip embedding), and were designed with an average life span of ten years (INEC FACTSHEET on PVCs and Card Readers, 2015). The PVC has an embedded chip that contains all the biometrics of a legitimate holder, including fingerprints and facial image. On election day it would be swiped in a smart card reader at the polling unit to ensure 100 per cent authentication and verification of the voter before he or she would be allowed to vote. The PVC has security features that are not easily susceptible to counterfeiting. Only voters who had their PVCs were allowed to vote in the 2015 general elections. The PVCs were available for collection at distribution points in the 36 States of the country and the Federal Capital Territory (FCT) until Sunday, $8^{\text {th }}$ March 2015. 


\section{Smart Card Readers (SCRs)}

Smart card readers, on the other hand, were used for the first time in Nigeria's electoral history for the 2015 general elections through electronic voter authentication. The card reader uses a highly secure and cryptographic technology that is commonly used in devices that need to perform secure transactions, such as pay terminals. It has ultra-low power consumption with a single core frequency of $1.2 \mathrm{GHz}$ and an Android 4.2.2 operating system. The card reader units were supposedly subjected before the elections to quality assurance, integrity and functionality testing, and were found reliable in terms of ease of use, battery life and speed of processing. In theory, voter authentication was to take an average of ten seconds; however, experience varied as the reader failed on several occasions. This was despite the fact that the card readers were subjected to stress testing in some states and the FCT ahead of the elections on 28 March and 11 April 2015 (INEC FACTSHEET on PVCs and Card Reader 2015).

Indeed, on 7 March 2015, INEC went to the field to test run the reliability of the PVCs and the SCRs ahead of the elections. The trial took place in 225 out of the total 120000 polling units and 358 out of the 155000 voting points that were to be used for the elections (Thisday 2015). While there were some hiccups, the exercise was generally considered a good outing across 12 States in the six geopolitical regions of the country. The field reports largely justified the objective of the exercise: to verify PVCs presented by voters at polling units to ensure that they are genuine; and to biometrically authenticate the person who presents a voting card at the polling unit to ensure that he or she is the legitimate holder of the card. The real objective of the experiment was to ensure that only eligible voters exercised their franchise, and that only such legal votes would be counted and tallied. To this extent the introduction of this technology was justified. However, the technical problems experienced were significant enough for many political stakeholders to express misgivings about its workability, while some canvassed outright for its non-use or postponement. Overall, a verdict on the success or otherwise of this electronic technology depends on its overall contribution to the transparency and credibility of the elections.

According to the Kayode Idowu, chief press secretary to the INEC Chairman, the use of these card readers has enormous advantages. These include the fact that once configured, the card reader can read only PVCs issued by INEC. Any person who shows up at the polling unit without a PVC or with a card not issued by INEC will not be able to vote. Also, the SCR reads the embedded chip on the PVC, not the barcode, and it shares a secret code with the PVC; thus it is impossible to falsify the cards. The card reader authenticates the identity of the 
voter by cross-matching his or her fingerprints with that stored on the embedded chip. No person can vote using another person's PVC. The card reader keeps a tally of all cards read, comprising the details of all voters verified as well as those not verified, and transmits the collected information to a central INEC server via GSM data service. Information transmitted to the server will enable INEC to audit results from polling units, as well as do a range of statistical analysis of the demographics of voting. Further, collation officers will also be able to use information transmitted by the card reader to audit polling unit result sheets and determine whether accreditation figures have been altered (Idowu 2015).

The use of the card reader to accredit voters is one of the innovations introduced by the Commission to improve the integrity of the electoral process. It does not violate the Electoral Act 2010, as Amended, or the 1999 Constitution of the Federal Republic of Nigeria, as Amended. It adds value to the process in line with the yearnings of Nigerians for credible elections, and accords with international best practice. Whereas the Electoral Act prohibits the use of electronic voting, the SCR is not a voting machine and is not used for voting. The card reader is used only for the accreditation of voters, and only accreditation (and not voting) data is transmitted by it.

To prevent fraudulent use, the card reader was configured to work only on election days. In addition, the device was configured to specific polling units and could not be used elsewhere without requiring reconfiguration by authorised INEC personnel. The commission procured more than 35000 back-up batteries that could be rapidly deployed in the event of failure during use, as well as 26000 spares for card readers (Idowu 2015). This was necessary as a result of observations made from the use of SCRs in Ghana's 2012 general elections.

\section{Parties, Polemics and the Smart Card Reader}

Polemics over the use of the SCR continued with accusations and counter accusations between the two major parties, the PDP and APC, on the merits and de-merits of its use and possible designs for rigging by either of the parties. The hitches observed during the test-run of the SCR were significant enough to renew the rivalry between both parties in an already highly polarised political climate. While the APC hailed the outcome of the exercise as an impediment in order to 'manipulate the coming elections', the PDP dismissed it and asked that the usage of SCRs in the crucial election be shelved. The National Publicity Secretary of the party, Olisa Metuh, believed the outcome of the test 'vindicates earlier widespread calls by stakeholders that the card readers should be thoroughly tested to ascertain their workability before the general elections' (Thisday 2015). The PDP's position was strangely supported by some 15 fringe political parties which signaled their 
unpreparedness to go to polls if the electoral body went ahead with the card readers at the polls. Indeed, other interest groups went beyond verbal challenges as they lodged complaints against the use of the card readers in courts of law for appropriate interpretation, claiming its use would contravene the 2010 Electoral Act as amended, as well as the 1999 Constitution.

Further, the INEC exercise of collating PVCs and continuous registration in 12 States did not go that well, and INEC blamed this on computer error. Those who raised their voices against the use of the new technology for voter accreditation argued that the INEC Chairman Attahiru Jega should have used the technology on a smaller scale during the governorship election in the states, before using the technology full scale during the national election. However, in principle Nigerians welcomed the idea of the innovation as they hoped it would help stem the tide of electoral malpractice in the country. What was worrisome for many was the timing which became an issue as Jega waited for almost four years before triggering arrangements for the use of the SCRs. Many believed the INEC Chairman did not do a comprehensive test-run of the SCRs; and that INEC staff and ad-hoc staff were not properly trained in how to handle the card readers (Odiakose 2015).

INEC, which initially insisted that only those cleared by the SCR would be allowed to cast their votes, later came up with the idea of an incident form for those whose fingerprints the card readers could not read. That there were several incidences of SCR hitches was not in doubt. Even then President Goodluck Jonathan, the presidential candidate of the PDP in the polls, and his wife, were not spared. After several failed attempts with five card reader machines that tried to read his thumbprint, Jonathan and the First Lady were eventually issued with incident forms for accreditation. In Enugu, a similar incident played out which compelled the Deputy Senate President, Senator Ike Ekweremadu, to advise the Independent National Electoral Commission to discard the use of SCRs for the polls after he could not secure accreditation with the machine. Ekweremadu was also eventually accredited with the incident form. According to Ekweremadu, the card reader should have been tried in a by-election or supplementary election before the main election. In Ebonyi State, the card readers failed woefully, a development that compelled electoral officials to hand out incident forms to accredit voters. Secretary to the Government of the Federation (SGF), Senator Anyim Pius Anyim, who is an indigene of the state, instructed INEC to correct the lapses in the accreditation process linked to the SCRs in order to give credibility to the polls (Odiakose 2015).

It is important to note that some INEC officials attributed the failure of the card readers to INEC engineers who could not decode the inbuilt security 
installation in the card reader. The security code in the card reader is reportedly designed to update the time and date of voting. One official claimed that the cards were initially programmed for February 14 , and that with the postponement to March 28, some of the cards had to be re-programmed (Odiakose 2015).

Following the failure of the card reader machines in several places, Attahiru Jega changed the guidelines for the conduct of the election on March 28. He approved the use of manual accreditation in areas where the SCRs malfunctioned during the presidential and National Assembly elections. In a statement issued while the election was under way, and after millions of frustrated voters had gone home disenchanted, INEC admitted that accreditation had been slow in many places and had not commenced at all in some others. INEC said that 'even though the guidelines for the 2015 general elections provide that where card readers fail to work and cannot be replaced, elections in such Polling Units will be postponed to the next day'. The scale of this challenge necessitated a reconsideration of the guidelines. The commission therefore decided that in polling units where card readers failed to work, the presiding officer was to accredit voters manually. In addition the presiding officer was to mark the voter's register upon being satisfied that the person presenting the PVC was the owner.

There was also the troubling issue of underaged voters issued with PVCs in the north of the country during the March 28 polls. Some of the states identified in this malpractice were Kano, Jigawa, Katsina, Gombe, Bauchi, Katsina, and Kogi States (Nnaji 2015). A team of European observers led by Dirk Verheyen and Joelle Meganck had decried the spate of underage voting that characterised the election in the north. They reported that minors presented valid PVCs. How did this happen? Perhaps we deserve some answers from INEC. Further, INEC was accused of voter suppression in the south through the instrumentality of the PVCs. For example, while there were about 5 million voters from the south east in the 2011 elections, only 2.6 million votes were recorded in 2015. In contrast, the total votes from Jigawa and Kano States (Jigawa used to be a part of Kano State), was 3.1 million, even double that of Lagos State, which had only 1.4 million (Nnaji 2015). Several months before the election the issue of underage voting was brought to the attention of INEC, and Jega's response was not really convincing as he only stated that any underaged voter to present himself or herself to vote on election day would be arrested. In spite of Jega's assurances, thousands of underaged voters were alleged to have been allowed to vote on March 28. If this is true, it is not a good development for our democracy. And if this act goes unchecked and the culprits remain unpunished, it may encourage other regions in the country to also engage in such malpractice in future elections. 


\section{ELECTORAL FRAUD IN THE 2015 ELECTIONS}

It is against the backdrop of the polemics generated by the use of the PVCs and SCRs that the presidential and National Assembly elections were held on 28 March and 11 April 2015. While the elections were largely satisfactory, the electoral process and results from the two states of Rivers and Akwa Ibom were fundamentally conflictual and hotly contested. In both states, it appeared that either the PVCs or SCRs were side-lined, or that they were seriously compromised. Following the large number of votes churned out during the elections in these two states, the Nigerian police instigated investigations into allegations of electoral fraud or rigging in both. The Rivers State Resident Electoral Commissioner (REC), Mrs. Gesila Khan, and her Akwa Ibom counterpart were to be investigated for alleged electoral fraud. The Rivers State APC Chairman, Dr. Davies Ibiamu Ikanga, had repeatedly called for an investigation of the 28 March and 11 April elections in the state. The belief is that the results of the elections were manipulated by the Rivers REC due to 'orders from Abuja' (Daily Times 2015, p.8). It is important for Nigeria's democracy to determine whether the malpractices observed in these states were as a result of the non-use of the SCR or whether the device itself was compromised.

From the results presented by the returning officer (RO) Osasere Orumwense, Chief Nyesom Wike of the PDP was awarded 1029102 votes, representing $87.8 \%$ of 1228614 being the conjured number of total accredited voters (Daily Times 2015, p. 11). However, according to the 94 page INEC endorsed document, the total number of accredited voters for the 11 April gubernatorial election in Rivers was 292 878. This document was signed by the Acting Director in charge of INEC legal unit, Ibrahim Bawa and Head of Unit, Data Management of the Commission's ICT Department, Abimbola Oladunoye (Daily Times 2015, p.11). In the document detailing polling unit analysis of actual voters' accreditation for the election, none of the 23 Local Government Areas (LGAs) had as many as 51000 accredited voters. Rivers State had 319 Registration Areas (wards) and 4442 polling units. Informed sources believe that the only logical explanation for the increased number of accredited voters exceeding 292887 is if manual accreditation was used in addition to the use of SCRs. Conversely, INEC did not approve the use of manual accreditation for governorship election in any of the federation states (Daily Times 2015).

According to the statement from the INEC Chairman, the purpose of the card reader is to prevent electoral fraud, especially falsification of the number of accredited voters in order to inflate the number of votes cast. Inside information revealed that the number of accredited votes generated by the Commission's central server is the authentic number for the Rivers State Governorship Election; 
hence, it will be impossible to justify the excess number of votes allocated to it. This is thus a good case for the Election Petition Tribunal. Indeed, the APC, which lost the election, went to the tribunal for help. Interestingly enough Governor Nyesom Wike of the PDP recently requested that the Rivers State Election Petition Tribunal set aside the order it made for the opposing party (the APC) to inspect election materials used for the 11 April 2015 Governorship polls in the state (Ughegbe 2015, p.15). The petitioners had urged the court to order the inspection of SCRs and records of electoral materials used in all the polling units in the State. This begs the question of why any stakeholder would resist the inspection of materials that could vindicate him or her from accusations of rigging or electoral fraud.

Akwa Ibom State, for example, experienced violence that characterised their gubernatorial and House of Assembly elections. This included several allegations of malpractice against the State's Resident Electoral Commissioner (REC). As a result the governorship candidate of the APC in the State, Umana Umana, called for the cancellation of the elections, accusing the PDP of state terrorism. According to him, electoral materials were unavailable in many polling units in all the three senatorial zones, and both ballot boxes and sensitive election materials were snatched (Azimazi 2015, p.4). In a report by Premium Times (2015), INEC officials in some polling units colluded with supporters of a political party to rig the presidential election in favour of their party. The claim is that whereas INEC officials had completed voters' accreditation as early as $1.30 \mathrm{pm}$, they refused to commence voting until some chieftains of the political party arrived at $4 \mathrm{pm}$. The party chieftains immediately ordered all voters to move away from the polling centre, which they successfully ensured by firing gunshots. This gave the party chieftains the opportunity to have a field day thumb-printing ballot papers under the supervision of INEC officials. In this case, the rigging appears to have been made possible by political violence, and not necessarily the use of the PVC and SCR.

Indeed, it did appear that there were more incidences of electoral rigging in the south-south zone of the country, namely, Rivers, Akwa Ibom, and Cross River, than in other parts of the country. This could be due to a deliberate attempt to subvert the process, or a technological failure. However, it is important to note that in spite of all these alleged electoral malpractices, a key actor in the process, the presidential candidate of the APC Muhammadu Buhari, declared that the introduction of the PVC and biometric card reader by INEC ensured free, fair and credible polls in 2015. According to him, the votes would not have been counted but for these initiatives. He noted that in previous riggings, results were written in party offices and sitting rooms and announced on radio stations and television houses, while those who protested were often asked to go to court (Abuh \& Azimazi 2015, p.7). Who best to know this but Buhari, as he had contested the presidential elections a record of four times. 


\section{LESSONS LEARNED AND POTENTIAL FOR FUTURE}

Several lessons could be learned from the use of the PVC and SCR in the 2015 presidential and general elections. The key lessons revolve around the gains made in ensuring increased credibility for the electoral process, but also in respect of the problems encountered in the use of technology. It is equally necessary to note that the use of this technology did not necessarily stop the usual problems encountered during elections in Nigeria. The presidential polls witnessed automatic attacks by Boko Haram in the north east. This led to the death of six persons, breaches of security in Enugu and Awka, shootings in Lagos and Imo States, and an explosion in Jigawa state (Musari 2015). There were riggings in the general elections despite the use of PVR and SCR technology. These include underage voters with PVCs in the north of the country, over-counting, double voting, cancellations, and hijacked ballot papers as experienced in Cross River and Akwa Ibom states. The INEC Chairman's frequent comment was that no election is perfect, and indeed this is true. The important thing is that overall the election satisfied minimum expectations, and the overwhelming wish of the electorate.

Some of the easily observable problems from the 2015 elections include:

- the slow process of accreditation (procedures should be reduced to save time)

- the card reader's inability to capture thumbprints of some eligible voters who had their PVCs

- late arrival of election materials

- breaches of security

- collusion of some INEC staff in undermining the voting process

- the inadequate preparation of some INEC staff and voters for the exercise.

In many cases during the election, the verification of PVCs lasted up to 10 minutes, thereby slowing down the process. This was exactly the case during the test-run of the PVC and SCR in Nassarawa, Rivers and Ebonyi, where the SCRs recorded significant failures (Thisday 2015). One would have thought that INEC would have taken adequate measures to avoid this occurring again. It could however, be opined that the true winners in the 2015 Presidential election were the electronic biometric device and the Nigerian voter. This technology should be further improved and factored into the 2019 general elections. Electronic voting could also be explored in the future starting with upcoming gubernatorial elections, if approved by the National Assembly and embodied in the Electoral Act.

Again, the use of the PVC and SCR may have revealed certain details of 
Nigeria's population and demography long suspected to be false. The 2015 elections recorded 10 million voters less than in the 2011 elections (Nkemdiche 2015, p.17), begging the question of where all the votes came from in the 2011 elections. The presidential election was won by a margin of only 2.5 million votes, the smallest margin in presidential elections since the Fourth Republic. This technology therefore has considerable potential for national planning and the verification of existing national data.

\section{CONCLUSION}

The expectation was that the use of the SCR would eliminate malpractices and election rigging and add to the credibility of the elections. To a large extent this expectation was attained, and the votes counted despite some drawbacks; so it could be said that the progressives won. As observed, elections are credible when they are premised on a quantitative and qualitative national register of votes. Elections conducted on the basis of the foregoing become credible if they have popular participation, and citizen and ballot safety and securitisation (Umeagbalasi 2015, p. 39). In other words, election security still remains paramount for the safety of personnel and the election process, and must continue to be taken seriously. In spite of a few cases of malfeasance by the police in some states, it must be noted that for the 2015 elections the Nigerian police were very civil and performed above average, thereby giving the required security cover necessary for transparent and credible elections and for the SCR to be deployed.

The use of the card reader did help reduce the previous penchant to rig elections and thus subvert the electoral system. The expectation is that even in those instances where there were successful breaches of the electoral process, especially through the use of violence, the records in INEC's database, which are ordinarily immune to human manipulation, would be relied on and serve as tenable evidence at the Election Tribunal.

It is important to note that the 2011 Voter Register, the first electronically compiled voting register, served as the basis for the production of the PVCs used in the 2015 general elections. The successful deployment of the SCR during this election could serve as the precursor to making the voting process completely electronic in the 2019 general elections. The transparent application of this device and the security features embodied in it made it extremely difficult to compromise the elections, despite attempts to do so. This time, the Nigerian electorate won due to the measures taken by INEC, particularly by the introduction of the SCR. With technological modifications based on field experience during this election, the future is bright for democracy in Nigeria. 


\section{- REFERENCES}

Aborisade, F 2006, 'A case for credible elections in Nigeria: proposed agenda for electoral reform', The Constitution, vol.6, no.1.

Babalola, A 2003, Election law and practice, Intec Printers Ltd., Ibadan.

Abuh, A \& Azimazi MJ 2015, 'Buhari links credible 2015 polls to PVC, card-reader', The Guardian (Lagos), 7 May.

Adebisi, R 2015, 'INEC: A gamble with integrity', The Guardian (Lagos), 17 July.

Agbu, O 2016, Elections and governance in Nigeria's Fourth Republic, CODESRIA, Dakar.

Ahmada, S et al. 2015, 'Issues and challenges of transition to e-voting technology in Nigeria', Public Policy and Administrative Research, vol.5, no.4.

Azimazi, MJ 2015, 'Local election observers fault calls for voiding of Rivers, A'Ibom polls', The Guardian (Lagos), 15 April.

Daft, RL and Lengel RH 1986, 'Organisational information requirements, media richness and structural design', Management Science, vol.35, no.5.

Daily Times 2015, ‘Large votes: Rivers, Akwa Ibom electoral commissioners under investigation", 8 June.

DeSantis, G and Poole MS 1994, 'Capturing the complexity in advanced technology use: adaptive structuration theory', Organization Science, vol.5, no.2.

Eguavoen, AA 2009, 'Problems of elections and imperatives of reforms in Nigeria's democratic process', The Constitution, vol.9, no.3, September.

Enwere, C and Ibrahim L 2015, 'Understanding the role of technology in free and fair elections in developing countries', Journal of Social and Administrative Sciences, vol.2, September.

Gyford, P 2000, 'Theories of technological change and the internet', Retrieved from http://gyford.com/phil/uhel/social_chnage/technological.pdf2000-02-21, accessed 16 October 2016.

Idowu, K 2015, 'Card readers is configured to work only on election days-Idowu', March 21, 2015. Retrieved from www.http://leadership/news/419134/cardreaders-is-configured-to-work-only-on-election days-Idowu accessed 26 June, 2015.

Idike AN 2014, 'Democracy and the electoral process in Nigeria: Problems and Prospects of the e-voting option', Asian Journal of Humanities and Social Sciences (AJHSS), vol. 2, issue 2.

Idowu-Fearon, J 2015, 'Idowu-Fearon: sanctity of the 2015 elections', The Guardian (Lagos), 26 November.

Jega, A \& Hillier MM 2012, 'Improving elections in Nigeria: lessons from 2011 looking to 2015'. Africa Programme Meeting Summary. Retrieved from http:/ / www.chathamhouse.org/ sites/ files / chathamhouse/Public/Research/ Africa/040712Summary.pdf 
Jega, A 2014, Electoral Reforms in Nigeria: Prospects and Challenges, INEC.

Levan, C \& Ukata P 2012, 'Countries at crossroads 2012: Nigeria'. Retrieved from http: / / freedomhouse.org/sites / default / files / Nigeria\%20-\%20FINAL. pdf

Mackenzie, D \& Wajcman, J 1985, The social shaping of technology, Open University Press, Milton Keynes,

Markus, M \& Robey D 1988, 'Information technology and organisational change: causal structure in theory and research', Management Science, vol.34.

Moru, J 2004, 'Rethinking the Nigerian reform programme', Thisday (Lagos), June 23.

Musari, A 2015, 'AU, ECOWAS Declare Polls Credible', The Guardian (Lagos), 30 March.

Nkemdiche, A 2015, 'Relating presidential elections to national census', The Guardian (Lagos), 29 April.

Nnaji, A 2015, 'Underage voters: what role did they play in the polls?' Post Nigeria, retrieved from www.post-nigeria.com/under-agevoters-what-role-did-they-playin-the-polls, accessed 20 July 2015.

Nwangwu, C 2015, 'Biometric voting technology and the 2015 General Election in Nigeria', paper presented at the 'The two-day national conference on the 2015 General Election in Nigeria: the real issues', 27 - 28 July.

Odiakose, M 2015, Nigerian Pilot, 'INEC and the use of card reader', April 11, Retrieved from www.http:// nigerianpilot.com/inec-and-use-of-card-readers, accessed 27 June, 2015.

Odigie-Oyegun, J 2014, ‘We doubt Jonathan's willingness to organise free, fair elections in February 2015', The Guardian (Lagos), 20 November.

Okoh, A O 2005, 'The Independent National Electoral Commission (INEC) and election management in Nigeria: The 2003 General Election in perspective", The Constitution, vol.5, no.4, December.

Okolie, A 2005, 'Electoral fraud and the future of elections in Nigeria 1999 - 2003', Godwin Onu and Abubakar Momoh, Elections and democratic consolidation in Nigeria, Lagos, Nigerian Political Science Association.

Opeibi, O T 2009, Discourse, politics and the 1993 presidential election campaigns in Nigeria, Nouvelle Communications Ltd, Lagos.

Osundare, N 2015, "Nigeria's new found 'Change' and lessons", The News, 1 June. Premium Times 2015, 'Nigeria decides; video exposes INEC officials with PDP to rig elections", 30 March.

The National Democratic Institute (NDI) 2003, 'Election special', The News Magazine, vol.20, no.15.

ThisDay Newspaper 2015, 'INEC and Smart Card Readers', 17 March 2015, Retrieved from www.http:/ / thisday.com/articles/inec-and-smart-card-readers/204251, accessed 26 June, 2015. 
Transition Monitoring Group (TMG) 2007, An election programmed to fail: final report of the April 2007 General Elections in Nigeria, July.

Ughegbe, L 2015, 'Wike urges tribunal to withdraw order on inspection of poll materials', The Guardian (Lagos), 26 June, 2015.

Umeagbalasi, E 2015, 'Credibility, security challenges facing February polls', Vanguard, 8 January. 